\title{
Tomasz Figlus
}

\section{Uwagi na temat procesu ksztaltowania granic wsi w Polsce do końca XVIII wieku w kontekście morfogenetycznym}

\begin{abstract}
W artykule omówiono w zarysie proces kształtowania granic wsi w Polsce w średniowieczu i epoce nowożytnej. Analizy następstwa stosowanych procedur delimitacji oraz demarkacji granic w krajobrazie kulturowym wsi dokonano w świetle odpowiednio wyselekcjonowanego materiału źródłowego w konfrontacji z wynikami dotychczasowych badań geograficzno-historycznych w tym zakresie. W pracy podjęto także problem powiązania kwestii formowania granic z zagadnieniem pochodzenia form osadniczych w ujęciu morfogenetycznym. Pozwoliło to na wykrycie wielu prawidłowości i dało podstawę do ustalenia współzależności w sferze osadnictwa wiejskiego w okresie staropolskim.
\end{abstract}

Słowa kluczowe: granica, wieś, osadnictwo, morfogeneza, Polska.

\section{Wprowadzenie}

Granica stanowi immanentny element funkcjonowania krajobrazu osadniczego, będąc efektem zagospodarowania przestrzeni geograficznej, rozwoju stosunków prawno-administracyjnych, społeczno-kulturowych i gospodarczych. Pojęcie granicy wykazuje obszerny zakres semantyczny w badaniach geograficzno-historycznych. W szerokim ujęciu rozdziela ona sąsiadujące ze sobą obszary, domyka pewną część przestrzeni i w różnej formie uwidacznia się w terenie (Bański 2010). Kształtowanie granic jest procesem wykazującym zmienność czasową i zróżnicowanie przestrzenne. Ich formowanie, sposoby delimitacji oraz demarkacji są przedmiotem badań geografii historycznej w aspekcie rekonstrukcji krajobrazu historyczno-politycznego związanego z powstawaniem i funkcjonowaniem jednostek administracyjnych i podziałów własnościowych (Gloger 1903, Arnold 1951, Szymański 2009, Tyszkiewicz 2014). Przebieg granicy, dążącej z czasem do linearyzacji, stanowi efekt oddziaływania wielu uwarunkowań, i w związku z tym mógł podlegać w toku dziejów licznym modyfikacjom. Granica wyznacza jednocześnie kształt obszaru danej jednostki terytorialnej o zróżnicowanym stopniu trwałości jej funkcjonowania.

Procedura ustalania granic w krajobrazie kulturowym wsi w Polsce ma długa tradycję, sięgającą wczesnego średniowiecza. Jej znaczenie szybko wzrastało 
w warunkach postępującej feudalizacji stosunków społecznych, a wyznaczenie precyzyjnego zasięgu jednostek osadniczych wiązało się niewątpliwie z zagęszczeniem sieci osadniczej, ale przede wszystkim z koniecznością egzekwowania praw własnościowych przez posiadaczy ziemskich. Z czasem następowała stopniowa instytucjonalizacja i formalizacja procesu kształtowania granic. Upowszechniły się rozwiązania prawne umożliwiające wyznaczanie granic wsi oraz ich demarkację w terenie. Podziały gruntowe były sankcjonowane, znajdując odzwierciedlenie w materiale źródłowym, głównie w formie przywilejów i dokumentów sądowych, a w XVIII w. zyskując dodatkowe możliwości delimitacji w ujęciu kartograficznym (Gołaski 1969, Bartoszewicz 2012). W badaniach posługiwano się w sposób egzemplaryczny zapiskami w średniowiecznych źródłach kancelaryjnych i materiałach opisowych. Studiom poddano także wybrane mapy sądów podkomorskich, komisarskich, referendarskich i asesorskich o proweniencji nowożytnej. Ich selektywne wykorzystanie na potrzeby analityczno-porównawcze niniejszej pracy pozwoliło dokonać rekonstrukcji formowania granic, ukazując tym samym złożoność i wieloetapowość tego procesu. Wyniki przeprowadzonych analiz opartych na materiale źródłowym skonfrontowano ponadto $\mathrm{z}$ dotychczasowym stanem badań geohistoriograficznych na ten temat.

Niezwykle istotnym celem pracy okazało się również zbadanie zależności w zakresie powiązania kształtowania granic oraz pochodzenia form osadniczych. Badania objęły układy ruralistyczne charakterystyczne dla rozwoju nieregularnego osadnictwa wczesnośredniowiecznego oraz regularnych form związanych z procesem lokacji na prawie niemieckim i pomiarą włóczną, rozwoju struktur folwarcznych, aż po układy typowe dla początków kolonizacji olęderskiej, fryderycjańskiej i józefińskiej. Dzięki zastosowaniu metod retrogresywnych przy odpowiedniej interpretacji planu historycznego możliwe było wykrycie prawidłowości w odniesieniu do specyfiki formowania granic wsi (zewnętrznych i wewnętrznych) reprezentujących różne typy morfogenetyczne.

Zakres chronologiczny rozważań ograniczono do końca XVIII w. Było to związane nie tylko ze zmianą sytuacji geopolitycznej ziem polskich i zróżnicowaniem przestrzennym systemów prawno-administracyjnych. Wyraźniej zmianie uległy bowiem metody ustanawiania granic. W obrębie terenów zajętych przez poszczególne państwa zaborcze ukształtowały się różne systemy ewidencji gruntów w postaci katastru pruskiego, austriackiego oraz tworzenia rozmaitych tabel gruntowych w zaborze rosyjskim. Był to zatem punkt zwrotny w dziejach, stanowiący de facto początek formowania obrębu ewidencyjnego we współczesnym rozumieniu tego pojęcia (Felcenloben 2011). 


\section{Zagadnienia formowania granic wsi w średniowieczu}

Proces kształtowania granic wsi w okresie staropolskim odbywał się w sposób ewolucyjny wraz z rozwojem systemu prawno-administracyjnego, opartego we wczesnym średniowieczu na prawie zwyczajowym, zmiennym czasowo i zróżnicowanym przestrzennie, które następnie było sankcjonowane $\mathrm{w}$ formie aktów normatywnych i przybierało bardziej sformalizowaną oraz ujednoliconą strukturę. W świetle dotychczasowej historiografii można stwierdzić, że pojawienie się granic było odzwierciedleniem rozwoju i umacniania się ziemskiej własności prywatnej (Manteuffel 1929, s. 221-222). S. Łaguna (1875) zaryzykował nawet hipotezę, że samo pojawienie się własności było emanacją stopniowego wytyczania granic (por. Bardach i in. 1994). Niewątpliwie kluczowe znaczenie dla rozgraniczania dóbr ziemskich i pojedynczych osad wiejskich miał zatem proces stopniowej feudalizacji stosunków społecznych, która odzwierciedlała się także w sferze podziałów gruntowych.

W początkowym okresie formowania granic sięgano przede wszystkim do komponentów środowiska przyrodniczego. Można do nich zaliczyć odznaczające się $\mathrm{w}$ terenie formy ukształtowania powierzchni, obszary puszczańskie oraz elementy sieci hydrograficznej, takie jak rzeki, linie brzegowe jezior czy tereny zabagnione. Stanowiły one wyraźną barierę rozwoju osadnictwa i z tego względu świetnie nadawały się jako naturalne elementy graniczne (Dobrowolska 1961). Dopiero w późniejszym czasie, wraz rozwojem ekumeny coraz częściej zaczęto stosować antropogeniczne linie graniczne, ustalane arbitralnie na podstawie elementów zagospodarowania przestrzennego, a więc tkwiących w sferze krajobrazu kulturowego. Warto $\mathrm{w}$ tym kontekście podkreślić, że pierwotnie dominowały wyraźnie w krajobrazie wsi granice o charakterze strefowym. Ich szerokość była dość istotnie zróżnicowana i zależna od lokalnych uwarunkowań wynikających z charakteru bariery fizjograficznej oraz zagęszczenia sieci osadniczej na danym obszarze. W okresie wczesnego średniowiecza mieliśmy zatem do czynienia głównie ze specyficznymi strefami buforowymi oddzielającymi poszczególne skupiska osadnicze. Granice strefowe w fazie zaniku wspólnoty rodowo-plemenniej ulegały zaś stopniowemu kurczeniu (Myśliwski 1994). Wraz z powstawaniem nowym punktów osadniczych następowały zjawiska przemieszania gruntów sąsiadujących ze sobą wsi, co w praktyce przez długi czas uniemożliwiało efektywne rozgraniczanie poszczególnych jednostek osadniczych, a w późniejszym czasie nierzadko stawało się przyczyną zatargów i sporów granicznych. Charakterystyczna stała się w ten sposób swoista szachownica międzywsiowa, utrudniająca gospodarowanie, ale również wpływająca negatywnie na możliwości ustalenia zasięgu własności ziemskiej (Burszta 1958). 
Wraz z rozwojem osadnictwa rozpoczął się na wielką skalę proces linearyzacji granic wsi. Był on silnie uwarunkowany feudalizacją państwa opartego na stosunkach lennych, łączących najwyżej stającego w hierarchii społecznej seniora (suzerena) z jego wasalami. Zależności te w praktyce były sankcjonowane poprzez system własności ziemskiej, w którym władca dokonywał nadań ziemi na rzecz możnowładztwa świeckiego oraz duchowieństwa (Szczaniecki 1938, Korta 1961, Dobosz 2002, Modzelewski 1980). Powodowało to w praktyce konieczność rozgraniczania różnych typów własności ziemskiej w celu sprawnego gospodarowania i czerpania korzyści z beneficjów. Pozwalało też na bardziej efektywną akcję osadniczą w obrębie zwartych kompleksów majątkowych. Dążono zatem do jednoznacznego uregulowania stanu posiadania, czego bezpośrednią konsekwencją stała się wymuszona sytuacją prawno-gospodarczą konieczność demarkacji granic $\mathrm{w}$ terenie. W realizacji tego procesu zmierzano do osiągnięcia wyraźnych podziałów poprzez niezbędną eliminację powszechnych do tej pory enklaw na pograniczu poszczególnych jednostek osadniczych.

Najbardziej znaną i powszechnie stosowaną metodą kształtowania granic poszczególnych wsi, ale i całych kompleksów majątkowych, był tzw. ujazd. W świetle Stownika staropolskiego (1982-1987, s. 511) był to „objazd lub obejście posiadłości przez rozjemców w celu wyznaczenia jej granicy”, ale także „wytyczona urzędowo granica posiadłości”. Instytucja ujazdu bardzo szybko się rozpowszechniła, choć miała różny charakter i w praktyce odbywała się rozmaicie w zależności od okresu jej zastosowania oraz obszaru, na którym była prowadzona. Ujazd odnosił się do rozgraniczania istniejących już włości królewskich, kościelnych i rycerskich (szlacheckich) wydzielonych w wyniku nadań ziemskich, jak również wykorzystywany był w przypadku tworzenia w średniowieczu nowych osad wiejskich w fazie intensywnej kolonizacji wewnętrznej (Podwińska 1977).

Początki ujazdu jako formy wyznaczania granic wsi były bardzo silnie związane z kształtowaniem się struktur sąsiedzkich monarchii wczesnopiastowskiej, czyli opoli - łac. vicinia (Buczek 1970, Lalik 1976, Matuszewski 1991). Stanowiły one de facto jednostki terytorialne o charakterze mikroekumeny osadniczej (Podwińska 1971). Stanowienie władztwa gruntowego przez opola odzwierciedlało się prowadzeniem przez nie ujazdów (circuitiones), co w praktyce oznaczało wytyczenie granic wsi (termini villarum). Wskazane pojęcia łacińskie pojawiają się w materiale źródłowym w XIII w. w kontekście wyznaczania zasięgu przestrzennego osad, np. w dokumencie Przemysła II z 1277 r. dla klasztoru lubińskiego (KDW 1877, t. 1, nr 469) czy Konrada I z 1261 r. dla biskupstwa wrocławskiego (Schlesisches Urkundenbuch 1984, t. 3, nr 353). Jeden z najstarszych i jednocześnie najciekawszych opisów stosowania ujazdu w celu ustanowienia granicy zawarty jest $\mathrm{w}$ dokumentach fundacyjnych klasztoru cyster- 
skiego, ukazujących wytyczenie zasięgu dóbr ziemskich wokół Trzebnicy z lat 1203-1218. Ujazdu dokonał wówczas osobiście, według relacji, książę Henryk Brodaty w towarzystwie biskupa wrocławskiego oraz członków swego dworu (KDŚ 1959, t. 2, nr 130 i 193). Charakterystyczne jest następstwo czynności, które rozpoczynało się od zapalenia ogniska w części centralnej rozgraniczanego obszaru. Istotnym warunkiem rozpoczęcia ujazdu było widoczne słońce, według którego wskazywano kierunek ujazdu. Starano się wykorzystywać przy wyznaczaniu granic obiekty fizjograficzne np. strumienie, osie dolinne lub grzbietowe czy linie zasięgu lasu. $\mathrm{W}$ terenie niedostępnym w trakcie demarkacji pomocą służył wzbijający się w górę dym pochodzący z ogniska (Dziewoński 1952)

W czasach wczesnopiastowskich przywilej prowadzenia ujazdu posiadał osobiście władca, mając do dyspozycji wojewodów. W praktyce jednak często księcia zastępował delegowany przez niego urzędnik w postaci komornika lub podkomorzego. To oni dokonywali wytyczenia linii granicznej i zdawali relację księciu w sprawach spornych. Wskazany urzędnik musiał dokonać objazdu i przeprowadzić oznakowanie granicy przy udziale przedstawicieli opola oraz sąsiadów, którzy mogli wnieść sprzeciw w przypadku naruszenia ich praw własnościowych, czego przykładem jest decyzja Bolesława Pobożnego z 1278 r. (KDW 1877, nr 476) czy decyzje sądu książęcego z 1281 r. między własnością rycerską a biskupstwem włocławskim (Dokumenty kujawskie i mazowieckie... 1887, nr 43, s. 217). Warto dodać, że w jeszcze XII w. stosowanie ujazdu było rzadkością, stąd nierzadko wiązało się z nadaniem nazwy urzędowej Ujazd (np. Szulc, Dziewulski 1973). Akcja rozgraniczeń rozwinęła się bowiem na wielką skalę dopiero w XIII i XIV w. Za pomocą miedz oznaczano wcześniej jedynie nadziały pojedynczych gospodarzy, pomijając tereny pastwisk czy lasów użytkowanych przez wspólnotę wiejską (Modzelewski 1986). W świetle dotychczasowej historiografii można stwierdzić, że najwcześniej ustalanie granic za pomocą ujazdów nastąpiło na przełomie XII i XIII w. na Śląsku i w Małopolsce, na terenie Wielkopolski, Kujaw czy Mazowsza procedura ta upowszechniła się z opóźnieniem, bo dopiero w drugiej połowie XIII w. (Młynarska-Kaletynowa 1968). Dla przykładu w Polsce Centralnej ujazd zaczął odbywać się na większą skalę dopiero po 1285 r. w kontekście wyznaczania posiadłości biskupów kujawskich (KDP 1848, nr 126, por. Kossmann 1995).

Circuitio jako obchód graniczny, występujący często w postaci objazdu konnego (circum equitatio), wiązał się z demarkacją granicy, czego efektem było oznaczenie w terenie elementów wskazujących na jej przebieg. Niekiedy wykorzystywano jako fragmenty granic, jak wcześniej wspomniano, obiekty fizjograficzne w postaci rzeki, jeziora, kompleksu leśnego, naturalnego wzniesienia. Większe głazy odgrywały często rolę umownych punktów orientacyjnych. Elementem granicznym były nieraz pojedyncze drzewa, np. wierzby na terenach 
podmokłych. Zdarzało się, że wzmiankowano nawet lisie nory i jamy. Przeanalizowane na potrzeby artykułu materiały źródłowe na temat słownych opisów granic wybranych wsi obfitują w liczne elementy środowiska przyrodniczego, czego najlepszym przykładem jest analiza przebiegu granicy wsi Kolanówka, położonej $7 \mathrm{~km}$ na południowy zachód od Krosna (Stownik historyczno-geograficzny województwa krakowskiego... 1989, s. 712-720) czy wsi Łęgnowo, zlokalizowanej $6 \mathrm{~km}$ na południowy wschód od Wschowej (Stownik historyczno-geograficzny województwa poznańskiego... 1993, s. 25-26). Często jednak konieczne było stosowanie znaków sztucznych, stworzonych przez człowieka. Należały do nich rowy, wały, pale lub słupki, kamienie z napisem, a także ciosny, czyli nacięcia na drzewie albo kamieniu (Kiersnowski 1960, Tyszka 1995). Kopce ziemne o większych rozmiarach sypano w miejscu zejścia się kilku granic, co nazywano powszechnie angułami (scopuli angulares) stawianymi w miejscach narożnych, przy linii granicznej zaś umieszczano mniejsze kopce ościenne (scopuli parietales). Trzeba koniecznie podkreślić, że znaki graniczne były chronione prawnie, a ich naruszenie traktowano jak przestępstwo i rozstrzygano sądownie. Wyznaczniki te mimo późniejszych zmian granic w warunkach przemian agrarnych w XIX w. często przetrwały w krajobrazie kulturowym, stanowiąc reliktowy element dawnych podziałów administracyjnych i świadectwo kultury materialnej przodków. Nierzadko są wciąż obecne w świadomości lokalnej społeczności i stanowią istotny element sakralizacji przestrzeni (Jop 2011).

Funkcjonujące we wczesnym średniowieczu graniczne prawo zwyczajowe w różnych odmianach doczekało się wreszcie prób kodyfikacji (Kutrzeba 1949). Systematyzację rozwiązań prawnych w tym zakresie przyniosły niewątpliwie Statuty Wiślickie uchwalone za panowania króla Kazimierza Wielkiego. Ich postanowienia dawały podstawę do zastosowania jednoznacznej procedury wyznaczania granicy „między dobrem stołu królewskiego” a występujących o rozgraniczenie właścicieli ziemskich. Demarkacja prowadzona była przez delegowanych w tym celu dwóch dostojników oraz podkomorzego. W statutach określone były honoraria dla przeprowadzającego czynności ustalenia granicy, w zależności od tego, ile czasu ono trwało. Co istotne, prawo gwarantowało nienaruszalność granicy, przewidując odpowiednie sankcje za niszczenie znaków granicznych czy też samowolne działania związane z rozgraniczeniem posiadłości (Statuta Polskie... 1847). W późnym średniowieczu nastąpiła stopniowa zmiana pragmatyki stosowania ujazdu. Mianowicie prerogatywy wojewodów w sprawach spornych kwestii granicznych przejęli sędziowie ziemscy, natomiast podkomorzowie stali się urzędnikami ziemskimi, którzy w sprawach istotnej wagi lub sytuacjach dyskusyjnych uczestniczyli w czynnościach rozgraniczenia dóbr. W wielu przypadkach mniejszej rangi wizji lokalnej dokonywał dawny 
komornik, któremu towarzyszył woźny (Bujak 2001, s. 171-173). W przypadku, gdy demarkacja dotyczyła ustalenia granicy ziem królewskich z prywatnymi, to zgodnie z Przywilejem Kazimierza Jagiellończyka (Cerkwica 1454 r.) rozgraniczenia dokonywało dwóch urzędników wyznaczonych przez króla oraz podkomorzy, co potwierdzało wcześniejszą praktykę w tym względzie. W 1496 r. król Jan Olbracht rozszerzył to postanowienie, wyznaczając do rozstrzygania sporów z dobrami królewskimi dwóch komisarzy (dygnitarzy zamieszkujących na spornym terenie) oraz dwóch niższych urzędników z właściwym komornikiem (Rymaszewski 1978). Należy wyraźnie zaznaczyć, że kwestie własności ziemskiej począwszy od końca XIV w. odnajdują swe odzwierciedlenie w postaci zapisów zawartych w księgach sądowych ziemskich i grodzkich. Usankcjonowane były w ten sposób wszelkie umowy kupna i sprzedaży, transakcje skutkujące nowym podziałem dóbr oraz efekty rozsądzania sporów granicznych. Należy dodać, że wzmianki na temat dokonywanych rozgraniczeń i ich sposobów w tym okresie są jednak często bardzo lakoniczne (por. Księgi sądowe łęczyckie... 1897, Księgi sądowe wiejskie 1920-1921).

Jak wcześniej sygnalizowano, istotnym celem pracy było powiązanie sfery morfogenetycznej wsi z kwestią wytyczania granic i ich cech geometrycznych. W okresie wczesnofeudalnym doszło w początkowej fazie rozwoju osadnictwa

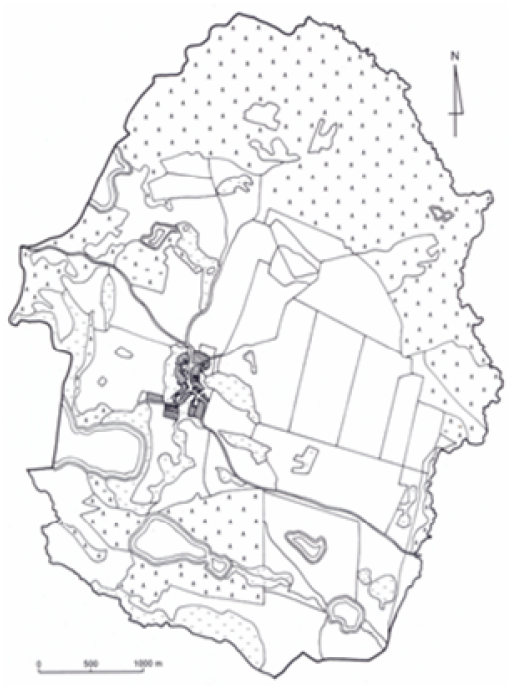

Ryc. 1. Wyszebórz. Odrys planu wsi z $1772 \mathrm{r}$.

Źródło: APK, sygn. Ks. Kam. Pl. W. 1/65 do powstania wielu, często izolowanych względem siebie osad jednodworczych, które z czasem ulegały samorzutnej metamorfozie we wsie wielodworcze, wypełniając tym samym pustki osadnicze. Pod względem typologii siedlisk do najpowszechniejszych typów należały wówczas wsie drogowe oraz rozdrożne, a ponadto okolnice, owalnice i wielodrożnice. Były to formy pierwotne, silnie dostosowane do lokalnych warunków fizjograficznych, które determinowały przebieg ich granic. Ich wspólną cechą były małe rozmiary oraz nieregularność układu przestrzennego. Przejawiała się ona $\mathrm{w}$ asymetrycznym położeniu siedliska $\mathrm{w}$ stosunku do granic wsi, brakiem wyraźnych granic zewnętrznych niwy domowej i nierówną wielkością, różnym kształtem oraz nieregularnym przebiegiem granic działek siedliskowych. Dobrze ilustrują to plany wsi Wyszebórz (ryc. 1) z 1772 r. (APK, sygn. Ks. Kam. Pl. W. 1/65; AHWP, tab. 3) 
i Miejsce Odrzańskie z 1795 r. (APW, sygn. KG Ko. 12; AHWP, tab. 32). Siedliskom towarzyszyły początkowo układy poloniarskie typowe dla osad samotniczych, a następnie drobnoblokowe. Wtórnie powstały z nich układy blokowo-pasmowe oraz składające się z wielu nieregularnych niw. Wykształciły się one w warunkach żarowej lub dwupolowej gospodarki rolnej (Fastnacht 1962, Szulc 1995).

Wraz z upowszechnieniem się procesu lokacji na prawie niemieckim dominowały siedliska wsi w postaci ulicówek, owalnic i innych wsi placowych. Były to zazwyczaj, oprócz łańcuchówek, charakterystycznych dla obszarów górskich oraz wyżynnych, formy naśladowcze, nawiązujące do typów rozplanowania znanych z okresu wczesnofeudalnego. Oprócz form inicjalnych powstałych w wyniku lokacji na tzw. surowym korzeniu, niektóre układy ruralistyczne rozwinęły się $\mathrm{w}$ wyniku reorganizacji przestrzennej wsi wcześniejszego pochodzenia. Charakterystyczną cechą siedlisk tego typu była ich regularność, przejawiająca się w centralnym położeniu siedliska w stosunku do granic wsi oraz zaplanowanym układzie drożnym. Niwa domowa miała kształt zbliżony do prostokąta, a jej granice zewnętrzne były zazwyczaj wyraźne, oddzielone od rozłogów prostoliniowymi miedzami lub drogami zagumnymi, co egzemplifikuje plan wsi Pysząca (ryc. 2) z 1799 r. (APP, sygn. Rej. Pozn. II 92; AHWP, tab. 47) czy Stare Chrapowo z 1753 r. (APS, sygn. NMP 13; AHWP, tab. 26). Okres lokacji na prawie niemieckim przyniósł powstanie układu niwowo-łanowego dostosowanego do trójpolówki oraz układu leśno-łanowego (Kozaczewski 1975, Tkocz 1998).

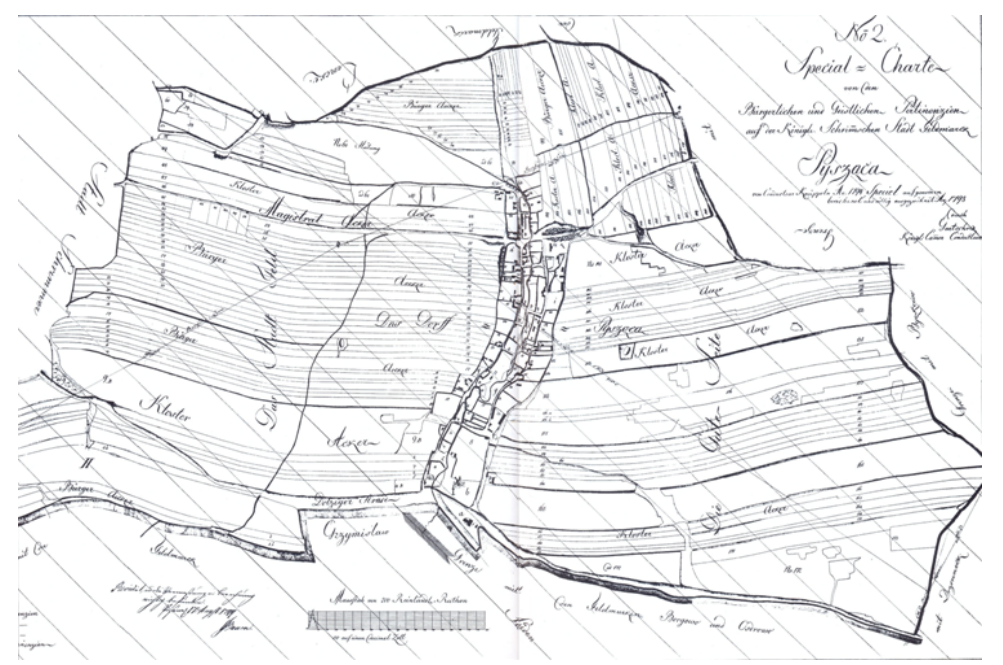

Ryc. 2. Pysząca. Plan wsi z 1799 r.

Źródło: APP, sygn. Rej. Pozn. II 92 
W świetle przeprowadzonej analizy przy zastosowaniu metod retrogresywnych można wskazać cechy rozplanowania wsi średniowiecznych w aspekcie kształtowania granic wewnętrznych, obejmujących podziały własnościowe, obecne zarówno w obrębie siedlisk, jak i rozłogów wiejskich (Figlus 2013). Wyraźnie zarysowuje się dualny podział w tym zakresie, uwzględniający nieregularne granice wewnętrzne wsi wczesnofeudalnych i regularny układ granic wewnętrznych wsi kształtowanych w okresie pełnego i późnego średniowiecza. Pierwsze powstały żywiołowo, w wyniku spontanicznej akcji osadniczej, drugie rozwijały się w sposób planowy przy zastosowaniu pomiaru gruntów opartego na funkcjonujących ówcześnie systemach metrologicznych.

Nieco inaczej przedstawia się kwestia granic zewnętrznych wsi średniowiecznych. Otóż mimo zasadniczych różnic w zakresie stopnia regularności podziałów wewnętrznych, trudno dostrzec bardzo wyraźną odmienność w przebiegu granic zewnętrznych, gdyż większość z nich pozostaje krzywoliniowa. Interpretacji tego stanu rzeczy należy doszukiwać się w samej istocie procesów osadniczych. Mianowicie lokacja, wbrew obiegowym opiniom, obejmowała w pierwszej kolejności zmiany statusu prawno-administracyjnego, a w znacznej części przypadków wiązała się z regulacjami rozplanowania. Repartycja gruntów i ponowne wytyczenie granic wewnętrznych nie powodowały najczęściej zmian zasięgu całej wsi. Bardziej regularne granice zewnętrzne o charakterze prostoliniowym mogły dotyczyć jedynie lokacji in cruda radice, które jednak stanowiły w bilansie osadniczym stosunkowo niewielki udział. O zróżnicowaniu granic zewnętrznych wsi średniowiecznych decyduje przede wszystkim nie charakter akcji osadniczej, lecz następstwo czasowe wydzielania poszczególnych wsi. Otóż najbardziej regularny układ granic wykazują osady najwcześniej ukształtowane $\mathrm{w}$ wyniku podziału pierwotnego na obszarze wcześniej niezagospodarowanym, niepodlegającym ekspansji osadniczej. W wyniku zastosowania ujazdu wsie tego typu mają kształt zbliżony do koła, którego regularność może być lokalnie zaburzona ze względu na wykorzystanie przy wytyczaniu granicy obiektów fizjograficznych. Doskonałym tego przykładem jest prezentowana wcześniej wieś Wyszebórz (ryc. 1).

Inny charakter granic zewnętrznych można dostrzec w przypadku, gdy do powstania nowej jednostki osadniczej dochodziło w wyniku wydzielenia jej z innej, wcześniej istniejącej wsi. W takiej sytuacji kształt wsi przypomina wycinek koła, którego znaczna część granicy jest pochodną wsi, z której się wykształciła. $Z$ tak opisanym wydzieleniem wtórnym mamy do czynienia nie tylko $\mathrm{w}$ średniowieczu w wyniku podziałów majątkowych wywołujących efekt tzw. pączkowania na płaszczyźnie osadniczej (Nowak 2003), ale także w epoce nowożytnej, szczególnie we wsiach szlachty cząstkowej i zagrodowej. O tym, która wieś powstała jako pierwsza, świadczy najczęściej uwypuklenie przebiegu 
granicy na styku obu osad, podczas gdy wieś powstała później wykazuje charakterystyczną wklęsłość granicy zewnętrznej w sąsiedztwie z osadą pierwotną. Hipotezę dotyczącą genezy wsi wysnutą w ten sposób należy oczywiście każdorazowo zweryfikować na podstawie dostępnego materiału źródłowego. W szcze-

gólnych sytuacjach dochodziło ponadto do wielokrotnego wydzielenia nowych wsi, często zróżnicowanych pod względem własnościowym, z większego kompleksu osadniczego. Wykształcona w ten sposób wieś składała się z wielu odcinków wklęsłych ku środkowi osady, co A. Oliskiewicz-Krzywicka (1999) trafnie nazwała sui genesis „resztówką książęcą”, rozwiniętą na bazie obszaru położonego między wsiami wcześniejszego pochodzenia.

\section{Wybrane aspekty wytyczania granic wsi w okresie nowożytnym}

Z jednej strony okres nowożytny przyniósł w pierwszej kolejności kontynuację, a jednocześnie rozwinięcie prawnych rozwiązań funkcjonujących już dość powszechnie w późnym średniowieczu na ziemiach polskich. $Z$ drugiej jednak strony pojawiły się instytucje i związane $\mathrm{z}$ ich działaniem procedury ukierunkowane na coraz bardziej sformalizowany proces wytyczania granic wsi i majątków ziemskich. Zaczęły stopniowo obowiązywać skodyfikowane czynności na gruncie postępowania sądowego, realizowane były innowacyjne metody rozgraniczania uwzględniające normy w zakresie sporządzania opisów granicznych i sposobów demarkacji linii granicznej. Na szeroką skalę upowszechniły się różne techniki prowadzenia pomiarów, które z czasem podlegały sukcesywnemu rozwojowi. Omawiany okres w badanym aspekcie formowania granic wsi zdecydowanie jednak nie ma charakteru jednolitego. Pewnym modyfikacjom ulegały stopniowo nie tylko rozwiązania prawne, w tym obejmujące aktywność nowych instytucji i działań urzędniczych z tym związanych. Nastąpiło w równym stopniu unowocześnienie stosowanych do tej pory metod demarkacyjnych, przekładających się na pragmatykę pomiarową. W tym kontekście podkreślić należy wyraźny rozwój miernictwa, który z czasem zaowocował pojawieniem się w zakresie czynności rozgraniczania zawodu mierniczego, biegłego w technikach geometrycznych realizowanych w terenie. W XVIII w. na szeroką skalę wykształcił się ponadto nowy materiał dokumentujący kształtowanie granic jednostek osadniczych i dóbr ziemskich w postaci planów gruntowych, które w znacznej mierze zrewolucjonizowały proces rozgraniczania. Pojawienie się wielkoskalowych źródeł kartograficznych stanowił niewątpliwie podwalinę pod współczesny rozwój informacji katastralnej opartej na technikach geodezyjnych.

Ze względu na brak istotnych dokumentów pomiarowych, ze szczególnym uwzględnieniem ujęć kartograficznych, we wczesnych etapach epoki nowo- 
żytnej informacji na temat metod rozgraniczania należy poszukiwać w źródłach pisanych. Okoliczności związane z obrotem ziemią lub w kontekście wszelkich sporów granicznych znajdowały swe odzwierciedlenie w materiale dokumentacyjnym w postaci ksiąg sądowych. Wzrost liczby transakcji wieczystych i spraw odnoszących się w swej istocie do ponownego rozgraniczania lub odnowienia granicy zaowocował prowadzeniem nowych form kancelaryjnych w postaci ksiąg podkomorskich. Dla przykładu pierwsza księga tego typu w Wielkopolsce dotycząca województwa poznańskiego zaprowadzona została począwszy od $1564 \mathrm{r}$. Zakres materiałów ujętych $\mathrm{w}$ ten sposób jest bardzo zróżnicowany w poszczególnych regionach kraju. Ewolucji podlegała także zawartość ksiąg wraz z upływem czasu. Różnie przedstawia się także kompletność materiału źródłowego. Treść zachowanych do dziś ksiąg podkomorskich, zwłaszcza w aspekcie rozstrzygania sporów granicznych, daje jednak wyobrażenie na temat metod ustalania granic w badanym okresie (Oliskiewicz-Krzywicka 2012).

W pierwszej kolejności warto wskazać najistotniejsze elementy procedury sądowej prowadzącej do ustalenia granicy. Rozgraniczenie mogło nastąpić w wyniku działalności procesowej lub na drodze polubownej w formie ugody (complanatio) lub arbitrażu (compromissum). Na wniosek powoda następowało wszczęcie postępowania sądowego o ustanowienie, odnowienie granicy lub w przypadku naruszenia granicy przez sąsiada. Po przesłaniu przez urząd podkomorski wszystkim zainteresowanym stronom specjalnego manifestu, w ustalonym terminie rozpoczynał się zjazd w terenie (condenscensio). Proces dotyczył całej granicy lub jej spornego fragmentu. Następnie przystępowano do wizji lokalnej polegającej na dokładnym prześledzeniu przebiegu duktu granicznego. Podczas obchodu ukazywano znaki graniczne, przedstawiano dokumenty, przesłuchiwano świadków. Decyzją podkomorzego określano stan faktyczny, ewentualnie rozstrzygano spór, po czym rozpoczynano stawianie znaków, począwszy od kopca węgielnego poprzez kolejne tzw. znaki ścienne do punktu wyjścia. Całość zwieńczała proklamacja ogłaszana przez woźnego, po czym składano uroczystą przysięgę. W przypadku dóbr królewskich rozgraniczanie przeprowadzała pięcioosobowa komisja z podkomorzym. Co istotne, nie przewidywano trybu ugody, a zeznania dzierżawcy nie miały mocy dowodowej (Gołaski 1959).

Abstrahując od dokumentacji formalnoprawnej, akta ujęte w księgach podkomorskich pozwalają prześledzić czynności wykonywane w zakresie rozgraniczania. Szczegółowość opisów dotyczących ustanawiania granicy jest dość mocno zróżnicowana. W dokumentach odnajdujemy informację na temat liczby kopców i innych znaków granicznych, ich rozmieszczenia oraz sposobach tyczenia linii granicznej w zależności od rodzaju użytkowania terenu. Co istotne, w XVI i XVII w. najważniejszy z punktu widzenia rekonstrukcji dawnych granic jest jej opis topograficzny. Zawiera on często bardzo precyzyjną charakterystykę prze- 
biegu duktu granicznego w zależności od sytuacji terenowej. Uwzględnione są przy tym elementy związane z układem pól, siecią drożną, szatą roślinną, obiektami hydrograficznymi, a także budynkami i urządzeniami technicznymi. W przeanalizowanych materiałach pochodzących z ksiąg podkomorskich poznańskich wspominano m.in. o układzie zagonów, gatunkach drzew w strefie granicznej, kierunku dróg oraz ich skrzyżowaniach i rozwidleniach, elementach rzeźby terenu, szczegółowo omawiano charakter strumieni czy jezior, wskazywano na położenie grobli czy młynów. $Z$ czasem niezwykle istotne znaczenie wykazywały również nazwy polne o ściśle określonej lokalizacji i zasięgu, zwane uroczyskami (APP, Sąd podkomorzego ..., sygn. 790, 782, 793, 796 za: Gołaski 1959).

W procesie wytyczania granicy starano się stosować odcinki prostoliniowe. Zmierzało to do uproszczenia przebiegu granicy w celu zapobiegania sporów. Oczywiście granice naturalne prowadzono zgodnie z położeniem obiektu fizjograficznego (np. środkiem rzeki). Mimo tendencji do prostowania, granice w praktyce często biegły jednak po lekkim łuku ze względu na pewne ograniczenia topograficzne. W oznaczaniu biegu granicy, jak wcześniej sygnalizowano, często usypywano kopce ziemne lub kamienne. Część kopców zabezpieczano za pomocą chrustu, cegły lub żużlu, co wydatnie podnosiło ich trwałość. W obrębie jezior czy terenów podmokłych wbijano odpowiednio zbrojone drewniane pale, nierzadko kopano także specjalne rowy. Funkcje znaków pełniły równie często pojedyncze drzewa znaczone naciosem w kształcie krzyża.

Ewolucji podlegało również miernictwo, które początkowo miało jeszcze dość prymitywny charakter, z czasem jednak ulegało udoskonaleniu. W dekretach podkomorskich można odnaleźć pojedyncze wzmianki z XVI i XVII w. na temat stosowania technik pomiarowych $\mathrm{w}$ trakcie wytyczania granic wsi. Jak nietrudno się domyślić, ograniczały się one do pól uprawnych, pomijane były niemal zupełnie na obszarach niedostępnych topograficznie i hydrograficznie. W zakresie dokonywanych pomiarów granic w aspekcie ich długości wykorzystywano przede wszystkim jednostkę sznura. W odniesieniu do odległości między znakami granicznymi stosowano najczęściej stajanie $(50,135$ i $240 \mathrm{~m}$ w zależności od okresu). Pół stajania wyznaczało najczęściej odległość między sąsiadującymi kopcami ściennymi. Na terenach niedostępnych długości te były jednak odpowiednio większe. W zakresie pomiarów poprzecznych do kierunku granicy często posługiwano się natomiast jednostkami mniejszymi, takimi jak łokcie, sążnie i kroki (Rychlikowa 1970, Dunin-Wąsowicz 1986).

W XVIII w. nastąpił wyraźny przełom w zakresie rozgraniczania jednostek osadniczych, jak i całych kompleksów majątkowych. Zmiany jakościowe odnosiły się w pierwszym rzędzie do udoskonalenia opisu topograficznego granicy w aspekcie określania kierunków oraz szczegółowości pozwalającej ukazać 
w sposób ciągły i dość precyzyjny przebieg duktu granicznego. W dużo większym stopniu aniżeli wcześniej zaczęto realizować postulat prostoliniowości linii granicznych na coraz większych odcinkach. W okresie tym dążono do większej stabilizacji przebiegu granicy na pomocą odpowiedniego oznakowania. Zaniechano w zasadzie stosowania naciosów na drzewach, podjęto działania na rzecz konserwacji znaków, starano się ujednolicać wygląd i parametry wielkościowe kopców węgielnych oraz ściennych. Zauważyć można stopniowe zagęszczanie znaków granicznych do odległości 20 prętów na odcinkach prostych i ok. 8 prętów na odcinkach krzywoliniowych (Gołaski 1961).

Wyraźne zmiany można dostrzec w zakresie pomiarów granicznych. Stały się one powszechne w każdej sprawie dotyczącej rozgraniczenia. Wzrosła także dokładność prowadzonych prac mierniczych przez biegłych geometrów. Zaczęto też stosować nowe jednostki miary, ze szczególnym uwzględnieniem prętów. Zasadnicza różnica $\mathrm{w}$ stosunku do wcześniejszego okresu odnosi się zatem do działalności geometrów w procesie formowania granic, ale również w aspekcie tworzenia kartograficznej dokumentacji ich działalności. Pierwsze plany gruntowe znane są co prawda ze źródeł już z końca XVII w. w kontekście przygotowania dokumentacji w sprawach apelacyjnych przed Trybunałem Koronnym. Były one jednak bardzo nieliczne i wykonywane prostymi metodami. Przełom w tym zakresie nastąpił dopiero w XVIII w., kiedy to wykonywanie planów $\mathrm{w}$ celach ustalania granic stało się powszechną praktyką. Wykonanie planów z oznaczeniem granicy de iure spoczywało na barkach podkomorzego. W praktyce jednak z uwagi na kompetencje wynikające ze stosowanych technik pomiarowych konieczne było zlecenie wykonania pracy specjaliście. W pierwszej połowie XVIII w. tworzenie planów nadal stanowiło rzadkość ze względu na relatywnie niewielką liczbę geometrów. Z czasem jednak ich liczba rosła, a w ślad za tym także zakres obowiązków. Do zwiększenia liczby uprawnionych geometrów wydatnie przyczyniła się uchwała sejmowa z 1768 r. Odtąd wszystkie sprawy rozpatrywane były cum optione conducendi geometrae iurati. Niewątpliwie plan dawał sądowi większe możliwości podjęcia decyzji w sytuacjach skomplikowanych, cechujących się znaczną rozbieżnością wariantów przebiegu granicy. Po wstępnych oględzinach duktu oczekiwano na wykonanie mapy przez geometrę, który swoje zadanie czynił najczęściej poza zjazdem granicznym, a jego bezpieczeństwo było zagwarantowane specjalnym dekretem (Tymowski 1970). Następnie dokonywano weryfikacji treści mapy z rzeczywistością na drodze objazdu. Zatem musiały być one wykonane starannie (diligenter confectae) oraz sporządzone według zasad geometrii (geometrice elaboratae). W końcu XVIII w. znaczenie mapy w ustalaniu granic było już bardzo silne. Mapy dawały możliwość faktycznej delimitacji, która poprzedzała późniejszą demarkację granicy w terenie. 
Tworzenie map na potrzeby rozgraniczania nie było tylko domeną sądów podkomorskich. Od początku XVI w. zaczęly kształtować się także sądy komisarskie. Rozstrzygały one głównie spory między dobrami królewskimi a prywatnymi oraz rozpatrywały podziały rodzinne. W podobnym czasie z sądu królewskiego wydzielił się ponadto sąd referendarski, który decydował w sprawach pomiarów gruntowych królewszczyzn oraz dóbr będących uposażeniem kasztelanów (Łonczyńska 1964). Funkcjonował także, wspomniany wcześniej, Trybunał Koronny jako najwyższy sąd szlachecki w sprawach cywilnych i karnych. Rozpatrywano w nim także w formie apelacyjnej wyroki w sprawach granicznych. W Archiwum Głównym Akt Dawnych znajduje się obecnie 156 map z XVIII w. w sprawach sądowo-granicznych, w tym 65 map podkomorskich, 10 map komisarskich, 7 map asesorskich, 2 mapy trybunalskie oraz 70 map sądu referendarskiego (Bartoszewicz 2012). Ich szczątkowy stan zachowania jest efektem wielu zniszczeń zasobu archiwalnego, szczególnie podczas drugiej wojny światowej (Figlus 2012). Świetnym przykładem ilustrującym technikę kartograficzną z pierwszej połowy XVIII w. (ryc. 3) jest mapa granic między dobrami duchownymi Złaków Borowy a dobrami szlacheckimi (AGAD, Zbiór Kartograficzny, sygn. 343-7). Rozwój miernictwa i metod kartograficznych w drugiej połowie XVIII w. ukazuje mapa sporu granicznego między dobrami Mazew, Głogowa i Jankowice wykonana przez S. Zambrzyckiego w 1786 r. (AGAD, Zbiór Kartograficzny, sygn. 170-6) czy mapa sporu granicznego między wsiami Howańczyce i Horbasów a wsią Markowa wykonana przez A. Jędrzejowskiego w 1772 r. (AGAD, Zbiór Kartograficzny, sygn. 500-17).



Ryc. 3. Mapa granicy między dobrami Złaków Borowy i dobrami Wrzeciona, pierwsza połowa XVIII w. Źródło: AGAD, Zbiór Kartograficzny, sygn. 343-7 
Analogicznie, jak w poprzedniej części artykułu, warto rozważyć zagadnienie formowania granic wsi w kontekście zróżnicowania morfogenetycznego. Pozwoli to ustalić, w jakim stopniu omawiane do tej pory procesy delimitacyjno-demarkacyjne odzwierciedlały się $\mathrm{w}$ sferze pochodzenia form osadnictwa wiejskiego. Rozważania należy rozpocząć od kwestii rozwoju struktur folwarczno-pańszczyźnianych, rozwijających się z różną intensywnością przez cały okres nowożytny. Długotrwałe zjawiska refeudalizacji stosunków społeczno-politycznych przyniosły zasadniczo powstanie wsi folwarczno-kmiecych oraz folwarczno-zagrodniczych. Pierwszy z wymienionych typów stanowił formę wtórną, o charakterze ewolucyjnym. W siedliskach tego typu folwark jako nowy element rozplanowania sprzężony był z zabudową kmiecą. Rzadziej powstawały w tym czasie autonomiczne osiedla folwarczno-zagrodnicze, w których obok folwarku funkcjonowała niewielka kolonia zagrodnicza. Biorąc pod uwagę specyfikę morfogenetyczną rozłogów, można stwierdzić, że wsiom folwarczno-kmiecym towarzyszył układ folwarczno-niwowy, cechujący się przemieszaniem własności dworskiej i włościańskiej. Zdarzały się jednak przypadki częściowej separacji nadziałów chłopskich $\mathrm{w}$ formie niwowej od położonych rozdzielnie bloków folwarcznych. Wraz z powstaniem wsi folwarczno-zagrodniczych rozwijał się natomiast układ folwarczno-blokowy, ewentualnie z niewielkimi nadziałami pasmowymi zagrodników. Przeprowadzona analiza zróżnicowania morfogenetycznego ukazuje, jak kształtowały się granice wewnętrznych podziałów gruntowych we wsiach folwarcznych. Były one zależne przede wszystkim od genezy folwarku, który mógł inicjować swój rozwój przestrzenny, opierając się na dawnych gruntach sołtysich, zagospodarowaniu nieużytków, karczowaniu lasów, a nawet rugach chłopskich. Wskazane możliwości rozwoju przestrzennego folwarku determinowały też $\mathrm{w}$ znacznym stopniu charakter granic zewnętrznych wsi, które mogły ulegać zmianom wraz z ekspansją gruntów folwarcznych ad extra. Ich zróżnicowanie mogło być też niewątpliwie skutkiem pierwotnej genezy wsi kmiecej, w obrębie której powstał folwark (Baranowski 1958, Figlus 2013). Zagadnienie granic wsi folwarcznych dobrze ilustrują plany wsi Owieczki (ryc. 4) z 1785 r. (APP Sąd Ref. 6; AHWP, tab. 45), Papowo Toruńskie z 1798 r. (APB, sygn. 1137a; AHWP, tab. 19) oraz Osiek z 1773 r. (APG, sygn. V/17-368; AHWP, tab. 5).

$\mathrm{W}$ omawianym okresie zidentyfikowano również powstawanie wsi w wyniku podziałów własnościowych oraz wsie protoprzemysłowe, w tym kuźnice, budy, smolarnie, huty oraz osady młyńskie i karczmarskie. Były to głównie osady samotnicze, przysiółki drogowe i placowe, powstające w wyniku spontanicznej akcji osadniczej i rozwijające się w sposób ewolucyjny. Towarzyszyły im zazwyczaj rozłogi w postaci nieregularnych bloków lub wtórnie układu blokowo-pasmowego. Abstrahując od granic wewnętrznych podziałów własnościowych, 
należy stwierdzić, że wsie tego typu rozszerzały swój zasięg przestrzenny w wyniku prowadzonej długotrwale działalności karczunkowej lasu. Odzwierciedlało się to $\mathrm{w}$ sukcesywnym rozwoju przestrzennym. Co za tym idzie, granice wsi często zmieniały swój przebieg, który wykazywał przy tym dużą nieregularność.

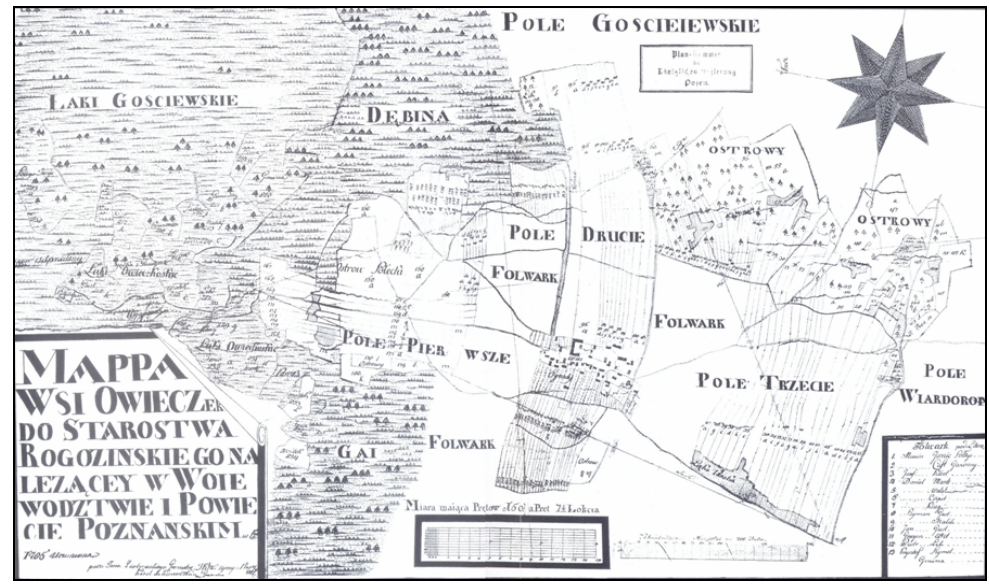

Ryc. 4. Owieczki. Plan wsi z 1785 r.

Źródło: APP, sygn. Sąd Ref. 6.

Zupełnie inaczej kształtowały się granice podziałów wewnętrznych oraz granice zewnętrzne tzw. szeregówek. Powstawały one sukcesywnie po 1557 r., czyli wraz z wprowadzeniem w życie reformy zwanej pomiarą włóczną. Przeprowadzona ona została na obszarze Wielkiego Księstwa Litewskiego, w tym na Podlasiu, które od czasu Unii Lubelskiej stało się częścią Korony. Osadnictwo przysiółkowe ustąpiło wówczas miejsce nowej fali osadniczej, która opierała się na uporządkowaniu stosunków własnościowych poprzez komasację gruntów. Siedliska wsi w ten sposób powstałych cechowały się bardzo dużą regularnością, porównywalną z wieloma wsiami średniowiecznymi, lokowanymi na prawie niemieckim. Rozłogi obejmowały rezy (płosy) zgrupowane w układzie trójpolowym, pomierzone precyzyjnie przy zastosowaniu włóki (Burszta 1958, Oliskiewicz-Krzywicka 2002). Co istotne, granice zewnętrzne szeregówek składały się przeważnie z odcinków prostoliniowych, które tworzyły zamknięty wielobok, wskutek czego wieś przybierała często kształt zbliżony do prostokąta lub kwadratu, czego dobrym przykładem może być plan wsi Ponizie z 1799 r. (AGAD, Zbiór Kartograficzny, sygn. 392-15; AHWP, tab. 97).

Kolejną kategorię morfogenetyczną stanowią wsie olęderskie i fryderycjańskie. Wsie olęderskie powstawały przez cały okres nowożytny z różnym natężeniem w poszczególnych regionach ziem polskich i opierały swój rozwój na zupełnie nowych warunkach prawno-administracyjnych i społeczno-gospodar- 
czych. Generalnie powstawały na obszarach do tej pory niezagospodarowanych, szczególnie na terenach podmokłych oraz puszczańskich. Pod względem genezy można w tym zakresie wydzielić wsie przejęte i ponownie zasiedlone, czemu towarzyszyła znacząca reorganizacja układu przestrzennego. Dominowały jednak osady nowo powstałe, założone in cruda radice. Pochodzenie form osadniczych jest przy tym kluczowe z punktu widzenia zrozumienia charakteru granic wsi. Biorąc pod uwagę cechy morfologiczne, zidentyfikowano głównie układy w formie rzędówek bagiennych bądź układy wsi rozproszonych pierwotnie. Rzędówkom bagiennym towarzyszył układ rozłogów w postaci nadziałów szerokopasmowych. W odniesieniu do osad rozproszonych można dostrzec natomiast obecność blokowego układu rozłogów. Przebieg granic zewnętrznych, a co za tym idzie kształt wsi, był silnie zróżnicowany: mniej regularny w przypadku osad rozproszonych oraz bazujący na prostoliniowej linii granicznej w odniesieniu do rzędówek bagiennych, z wyjątkiem odcinków, które swój bieg opierały na rzekach (Oliskiewicz-Krzywicka 2003, Figlus 2014). Dobrze ilustrują to plany wsi Holendry Radlińskie (ryc. 5) z końca XVIII w. (APP, sygn. Rej. Pozn. I 502; AHWP, tab. 73) oraz Nowołoskoniec z 1795 r. (APP, sygn. Rej. Pozn. I 339; AHWP, tab. 72).

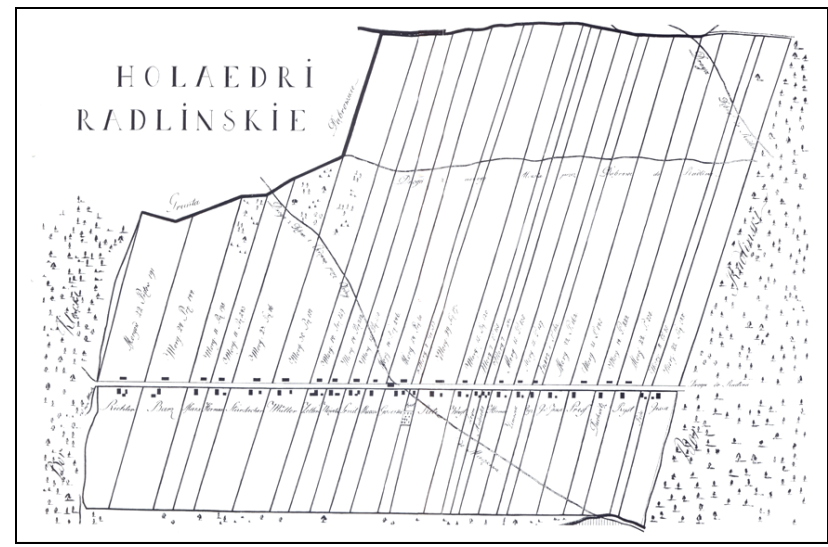

Ryc. 5. Holendry Radlińskie. Plan z końca XVIII w. Źródło: APP, sygn. Rej. Pozn. I 502

Kolonizacja fryderycjańska (w Prusach) i józefińska (w Austrii) stanowią ciekawy przykład kolejnej fali osadniczej rozwiniętej u schyłku XVIII w. Obie formy rozwijały się niemal równolegle i były prowadzone w zamiarze zagospodarowania niezasiedlonych i zapóźnionych gospodarczo terenów, ale też były uwarunkowane przesłankami natury społeczno-politycznej. Powstawały w obrębie własności rządowej, w dawnych majątkach królewskich oraz podlegających sekularyzacji dobrach kościelnych. 


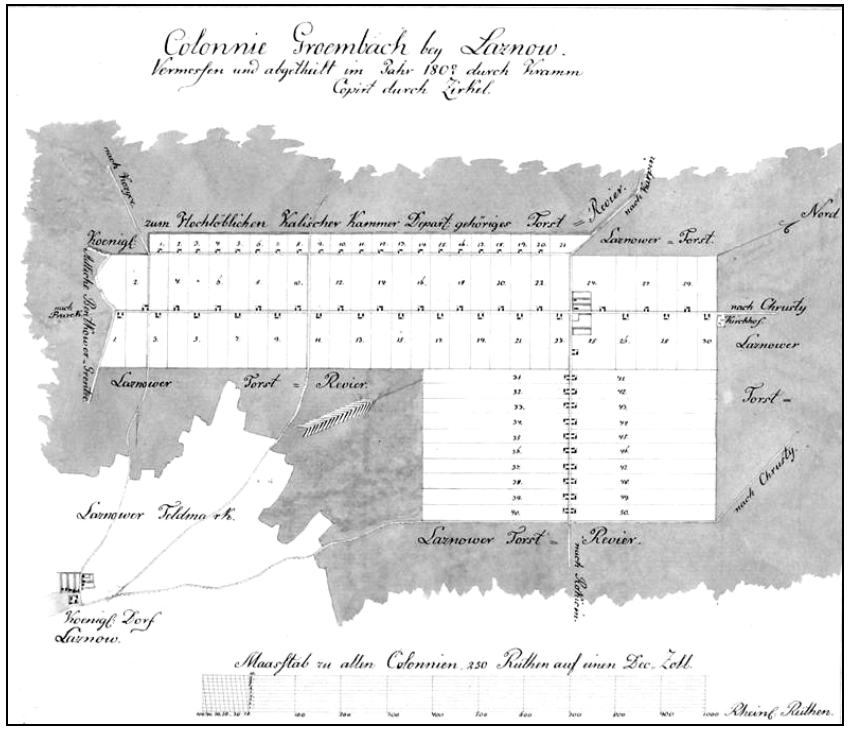

Ryc. 6. Plan kolonii Groembach z 1800 r.

Źródło: BUW, Gabinet Rycin, sygn. GR 300

Wśród wsi fryderycjańskich rozpoznano, oprócz dominujących układów przestrzennych $\mathrm{w}$ postaci zwartych typów ulicowych, także formy o oryginalnej formie wielobocznej, czego przykładem może być siedlisko w kształcie prostokąta, w formie krzyża czy też układ promienisto-koncentryczny, czego przykładem jest Nowosolna ukazana na planie z 1803 r. (AGAD, Zbiór Kartograficzny, sygn. 267-15). Przeważał wyraźnie pasmowy układ rozłogów, choć niekiedy odnotowywano nawet radialny układ pól (Zimmermann 1915, Lepucki 1938, Golachowski 1969, Woźniak 2013). Granice zewnętrzne wsi fryderycjańskich były bardzo regularne $\mathrm{z}$ uwagi na dokładne techniki pomiarowe i składały się w przeważającej mierze z odcinków prostoliniowych. W związku z powyższym kształt całej jednostki osadniczej przybierał na ogół postać prostokąta lub regularnego wieloboku, czego doskonałym przykładem jest wieś Groembach (ryc. 6) zobrazowana na planie z 1800 r. (BUW, Gabinet Rycin, sygn. GR 300).

\section{Podsumowanie}

Przedmiotem niniejszej pracy była analiza procesu rozgraniczania wsi w okresie staropolskim. Przeprowadzone badania oparte na materiale źródłowym, poddane konfrontacji z dotychczasowymi ujęciami problemu na gruncie badań geograficzno-historycznych osadnictwa, pozwoliły poczynić wiele interesujących spostrzeżeń oraz wykryć szereg prawidłowości tkwiących w sferze 
kształtowania granic w różnych skalach czasowych i przestrzennych. Udało się ukazać w zarysie genezę procesu formowania granic w średniowieczu. Zaprezentowano zagadnienie ujazdu jako zasadniczej formy prowadzącej do określania zasięgu przestrzennego jednostek osadniczych w okresie feudalizacji stosunków społecznych. Doprowadziło to do stopniowej likwidacji granic strefowych na rzecz powszechnej odtąd linearyzacji. Przebieg ujazdu zmieniał się wraz z kolejnymi próbami kodyfikacji prawa granicznego w średniowieczu. W wyniku analiz porównawczych rozplanowania wsi o metryce średniowiecznej możliwe było także przeprowadzenie wnioskowania na temat zróżnicowania przebiegu granic wewnętrznych i zewnętrznych osadnictwa wiejskiego w tym okresie. Pozwoliło to na wydzielenie regularnych i nieregularnych form rozplanowania obejmujących wewnętrzne podziały gruntowe. Przebieg granic zewnętrznych, a co za tym kształt wsi, zależny był natomiast głównie od następstwa czasowego powstawania punktów osadniczych.

W okresie nowożytnym proces kształtowania granic uległ dalszej instytucjonalizacji związanej z funkcjonowaniem instytucji sądowniczych, w tym sądów podkomorskich, referendarskich, asesorskich, komisarskich i trybunalskich. W tym kontekście zaprezentowano procedury demarkacyjne granic wsi, biorąc pod uwagę zagadnienia prawne, sposoby tyczenia linii granicznej oraz stosowane formy oznakowania $\mathrm{w}$ terenie. Istotną innowacją procesu rozgraniczania okazały się nowe techniki pomiarowe oraz zastosowanie metod wizualizacji kartograficznej w kontekście rozstrzygania sporów granicznych w XVIII w. Formy osadnicze o genezie nowożytnej okazały się niezwykle zróżnicowane pod względem podziałów wewnętrznych i granic zewnętrznych wsi. Wsie powstałe w wyniku pomiary włócznej oraz osady ukształtowane na skutek kolonizacji fryderycjańskiej i niektóre wsie olęderskie wykazywały duży stopień regularności, a wśród granic zewnętrznych wyraźnie dominowały odcinki liniowe, tworzące wieloboczne struktury przestrzenne. Znaczna część wsi z komponentem folwarcznym rozplanowania, osady protoprzemysłowe i część olęderskich były zaś zdecydowanie mniej regularne, zarówno pod względem wewnętrznych podziałów gruntowych, jak i granic zewnętrznych.

Podjęte w artykule badania mają charakter przyczynkarski i stanowią asumpt do dalszych analiz w odniesieniu do procesu rozgraniczania w sferze osadnictwa wiejskiego w Polsce. Warto podjąć szczegółowe badania regionalne oparte na dostępnym materiale źródłowym, jak również bardziej kompleksowe studia o charakterze porównawczym. Wydaje się ponadto wskazane przeprowadzenie dalszych badań opartych na metodach ilościowych, które dadzą możliwość obiektywizacji przebiegu granic i kształtów wsi w kontekście ich pochodzenia, dzięki zastosowaniu analiz morfometrycznych uwzględniających wybrane zagadnienia metrologii historycznej. 


\section{Literatura}

\section{Źródła}

Archiwum Główne Akt Dawnych w Warszawie (AGAD), Zbiór Kartograficzny, Mapa granicy między dobrami Złaków Borowy i dobrami Wrzeciona, I połowa XVIII w., 1:10000, sygn. 343-7.

Archiwum Główne Akt Dawnych w Warszawie, Zbiór Kartograficzny, Mapa sporu granicznego między dobrami Mazew, Głogowa i Jankowice, 1786, 1:9500, sygn. 170-6.

Archiwum Główne Akt Dawnych w Warszawie, Zbiór Kartograficzny, Mapa sporu granicznego między wsiami Howańczyce i Horbasów a wsią Markowa, 1772, 1:12250, sygn. 500-17.

Archiwum Główne Akt Dawnych w Warszawie, Zbiór Kartograficzny, Plan wsi Nowosolna, 1803, 1:15000, sygn. 267-15.

Archiwum Główne Akt Dawnych w Warszawie, Plan wsi Ponizie, 1799, AGAD, brak skali, sygn. 392-15).

Archiwum Państwowe w Bydgoszczy (APB), Plan wsi Papowo Toruńskie, 1798, 1:3000, sygn. 1137 a.

Archiwum Państwowe w Gdańsku (APG), Plan wsi Osiek, 1798, 1:5000, sygn. V/17-368.

Archiwum Państwowe w Koszalinie (APK), Plan wsi Wyszebórz, 1772, 1:5000, sygn. Ks. Kam. Pl. W. 1/65.

Archiwum Państwowe w Poznaniu (APP), Plan wsi Owieczki, 1785 r., 1:5100, sygn. Sąd Ref. 6.

Archiwum Państwowe w Poznaniu, Plan wsi Nowołoskoniec, 1795, 1:5000, sygn. Rej. Pozn. I 339.

Archiwum Państwowe w Poznaniu, Plan wsi Pysząca, 1799 r., 1:5000, sygn. Rej. Pozn. II 92.

Archiwum Państwowe w Poznaniu, Sąd podkomorzego województwa poznańskiego, sygn. 790, 782, 793, 796.

Archiwum Państwowe w Szczecinie (APS), Plan wsi Stare Chrapowo, 1753, 1:5000, sygn. NMP 13.

Archiwum Państwowe we Wrocławiu (APW), Plan wsi Miejsce Odrzańskie, 1795, 1:5000, sygn. KG Ko. 12.

Atlas Historyczny Wsi w Polsce (AHWP), 2002, opr. H. Szulc, Warszawa.

Biblioteka Uniwersytetu Warszawskiego (BUW), Gabinet Rycin, Plan kolonii Groembach,1800, sygn. GR 300.

Dokumenty kujawskie i mazowieckie przeważnie z XIII wieku, 1887, wyd. B. Ulanowski, „Archiwum Komisji Historycznej”, t. 4, Kraków, nr 43, s. 217.

Kodeks Dyplomatyczny Polski (KDP), 1848, t. 2, cz. 1, wyd. L. Rzyszczewski, A. Muczkowski, Warszawa, nr 126.

Kodeks Dyplomatyczny Wielkopolski (KDW), 1877, t. 1, wyd. I. Zakrzewski, Poznań, nr 469 i 476.

Kodeks Dyplomatyczny Śląska (KDŚ), 1959, t. 2, wyd. K. Maleczyński, A. Skowrońska, Wrocław, nr 130 i 193. 
Księgi sądowe łęczyckie od 1385 do 1419, 1897, cz. 1-2, [w:] Teki A. Pawińskiego, t. 3-4, Warszawa.

Księgi sądowe wiejskie, 1920-1921, t. 1-2, wyd. B. Ulanowski, Kraków.

Schesisches Urkundenbuch, 1984, t. 3, wyd. W. Irgang, Köln-Wien, nr 353.

Statuta Polskie Króla Kazimierza w Wiślicy złożone, 1847, wyd. K.W. Wójcicki, Warszawa.

\section{Piśmiennictwo}

Arnold S., 1951, Geografia historyczna, Warszawa.

Bański J., 2010, Granica w badaniach geograficznych - definicja i próby klasyfikacji, „Przegląd Geograficzny”, 82 (4), s. 489-508.

Baranowski B., 1958, Gospodarstwo chtopskie i folwarczne we wschodniej Wielkopolsce w XVIII wieku, Warszawa.

Bardach J., Leśnodorski B., Pietrzak M., 1994, Historia ustroju i prawa polskiego, Warszawa.

Bartoszewicz H., 2012, Z dziejów kartografii Mazowsza i ziem sąsiednich XVII-XX wieku, Warszawa-Pułtusk.

Buczek K., 1970, Organizacja opolna w Polsce średniowiecznej, „Studia Historyczne”, 13 (2), s. 205-248.

Bujak F., 2001, Studia nad osadnictwem Małopolski (reprint z 1905 r.), Poznań.

Burszta J., 1958, Od osady słowiańskiej do wsi współczesnej. O tworzeniu się krajobrazu osadniczego ziem polskich i rozplanowaniu wsi, Wrocław.

Dobosz J., 2002, Monarchia i możni wobec Kościoła w Polsce do początku XIII wieku, Poznań.

Dobrowolska M., 1961, Przemiany środowiska geograficznego Polski do XV wieku, Warszawa.

Dunin-Wąsowicz A., 1986, Metrologia historyczna o miarach agrarnych, „Kwartalnik Historyczny", 94, s. 409-423.

Dziewoński K., 1952, Geografia Trzebnicy i ujazdu trzebnickiego w okresie wczesnośredniowiecznym, „Studia Wczesnośredniowieczne”, 1, s. 25-34.

Fastnacht A., 1962, Osadnictwo ziemi sanockiej w latach 1340-1650, Prace Wrocławskiego Towarzystwa Naukowego, 84, Wrocław.

Felcenloben D., 2011, Granice nieruchomości i sposoby ich ustalania, Warszawa.

Figlus T., 2012, Wybrane aspekty zastosowania wielkoskalowych źródeł kartograficznych $w$ badaniach morfogenetycznych wsi, ,Biblioteka Polskiego Przeglądu Kartograficznego", 3, s. 91-103.

Figlus T., 2013, Morfogeneza wsi na obszarze Polski Środkowej, rozprawa doktorska wykonana pod kierunkiem M. Kuleszy, mps w BUŁ, Łodź.

Figlus T., 2014, Wsie olęderskie w Polsce Środkowej. Uwagi na temat zróżnicowania morfogenetycznego na tle rozwoju osadnictwa, „Rocznik Łódzki”, 62, s. 143-160.

Gloger Z., 1903, Geografia historyczna ziem dawnej Polski, Kraków.

Golachowski S., 1969, Studia nad miastami i wsiami śląskimi, Opole-Wrocław. 
Gołaski J., 1959, Technika rozgraniczania dóbr ziemskich w końcu XVI i XVII wieku w świetle poznańskich ksiag podkomorskich, „Przegląd Geodezyjny”, 31 (11-12), s. $449-455$.

Gołaski J., 1961, Technika rozgraniczania dóbr ziemskich $w$ XVIII wieku $w$ świetle poznańskich ksiąg podkomorskich, „Przegląd Geodezyjny”, 33 (5), s. 186-191; 33 (6), s. $228-232$.

Gołaski J., 1969, Ksztaltowanie się mapy wsi w Polsce do końca XVIII w. Studia nad geneza wielkoskalowej informacji kartograficznej, Monografie z Dziejów Nauki i Techniki, 60, Wrocław.

Jop R., 2011, Niematerialne wartości krajobrazu kulturowego w badaniach historycznych. Przykład granic i przestrzeni, [w:] Bernat S. (red.), Niematerialne wartości krajobrazów kulturowych, Prace Komisji Krajobrazu Kulturowego, 15, s. 91-102.

Kiersnowski R., 1960, Znaki graniczne w Polsce średniowiecznej, „Archeologia Polski”, 5, s. 257-289.

Korta W., 1961, Rozwój terytorialny wielkiej własności feudalnej w Polsce do połowy XII wieku, „Sobótka”, 16, s. 528-566.

Kossmann O., 1995, O staropolskim opolu, śląskim „weichbildzie” i szlacheckim powiecie, „Studia z Dziejów Państwa i Prawa Polskiego”, 2, s. 5-18.

Kozaczewski T., 1975, Wielkość, program i układ przestrzenny wsi z nawisem $w$ XIII wieku na Ślasku, „Kwartalnik Architektury i Urbanistyki”, 20 (2), s. 129-155.

Kutrzeba S., 1949, Historia ustroju Polski w zarysie. Korona. Historia ustroju Polski w zarysie, Warszawa.

Lalik T., 1976, Organizacje sqsiedzkie średniowieczne wsi polskiej-wieś, opole, parafia, „Kwartalnik Historii Kultury Materialnej”, 24, s. 440-456.

Lepucki H., 1938, Działalność kolonizacyjna Marii Teresy i Józefa II w Galicji 17721790, Lwów.

Łaguna S., 1875, O prawie granicznym polskim, Warszawa.

Łonczyńska K., 1964, Mapy Referendarii Koronnej w drugiej pot. XVIII w., „Kwartalnik Historii Kultury Materialnej”, 12 (3), s. 411-435.

Manteuffel T., 1929, Metoda oznaczania granic w geografii historycznej, [w:] Księga pamiątkowa ku czci M. Handelsmana, Warszawa, s. 221-227.

Matuszewski J., 1991, Vicinia id est... Poszukiwania alternatywnej koncepcji staropolskiego opola, Łódź.

Młynarska-Kaletynowa M., 1968, $W$ sprawie polskich badań nad osadnictwem średniowiecznym, „Studia z Dziejów Osadnictwa”, 6, s. 82-100.

Modzelewski K., 1980, Między prawem gruntowym a ksiązęcym władztwem gruntowym, Instytucja kasztelanii majątkowych Kościoła w Polsce XII-XIII w., „Przegląd Historyczny", 71 (3), s. 449-477.

Modzelewski K., 1986, Organizacja opolna w Polsce piastowskiej, „Przegląd Historyczny", 77 (2), s. 177-222.

Myśliwski G., 1994, Powstanie i rozwój granicy liniowej na Mazowszu (XII-poł. XVI w.), „Kwartalnik Historyczny”, 101 (3), s. 3-24.

Nowak T., 2003, Ze studiów nad rozwojem osadnictwa $w$ ziemi tęczyckiej $w$ czasach Wtadysława Jagietty, „Przegląd Nauk Historycznych”, 2 (3), s. 27-45. 
Oliskiewicz-Krzywicka A., 1999, Początki kształtowania się granic wiejskiego obrębu ewidencyjnego w Polsce, „Przegląd Geodezyjny”, 71 (12), s. 14-17.

Oliskiewicz-Krzywicka A., 2002, Kształtowanie się granic wsi na Podlasiu i Litwie w okresie od XIV do XVII wieku, ,Przegląd Geodezyjny”, 74 (4), s. 19-23.

Oliskiewicz-Krzywicka A., 2003, Kształtowanie się granic wsi w wyniku kolonizacji olęderskiej na terenie Wielkopolski, „Przegląd Geodezyjny”, 75 (6), s. 15-20.

Oliskiewicz-Krzywicka A., 2012, Spory graniczne $w$ XVIII wieku i ich wptyw na zmiany ksztattu granic, „Przegląd Geodezyjny”, 84 (3), s. 8-14.

Podwińska Z., 1971, Zmiany form osadnictwa wiejskiego na ziemiach polskich we wczesnym średniowieczu. Źreb, wieś, opole, Wrocław.

Podwińska Z., 1977, Ujazd, [w:] Słownik starożytności słowiańskich, t. 6, Wrocław, s. 251.

Rychlikowa I., 1970, Staropolskie miary ziemi, „Kwartalnik Historii Kultury Materialnej”, 18, s. 85-103.

Rymaszewski Z., 1978, Granicierum perequitatio w polskim prawie ziemskim, „Czasopismo Prawno-Historyczne", 30 (1), s. 41-64.

Słownik historyczno-geograficzny województwa krakowskiego w średniowieczu, cz. 2, 1989, A. Gąsiorowski (red.), Wrocław.

Słownik historyczno-geograficzny województwa poznańskiego $w$ średniowieczu, cz. 3, 1993, A. Gąsiorowski (red.), Poznań.

Słownik staropolski, 1982-1987, S. Urbańczyk (red.), t. 9, Wrocław.

Szczaniecki M., 1938, Nadania ziemi na rzecz rycerzy $w$ Polsce do końca XIII w., Poznań.

Szulc H., 1995, Morfogeneza osiedli wiejskich w Polsce, Prace Geograficzne, 163, Wrocław.

Szulc Z., Dziewulski W., 1973, Informator monograficzny - Ujazd Śląski 1223-1973, Strzelce Opolskie.

Szymański J., 2009, Nauki pomocnicze historii, Warszawa.

Tkocz J., 1998, Organizacja przestrzenna wsi w Polsce, Prace Naukowe UŚ, 1734, Katowice.

Tymowski J., 1970, Powstanie środowiska mierniczego $w$ Polsce i zarys jego historii do I wojny światowej, [w:] Zarys historii organizacji społecznych geodetów polskich, Warszawa, s. 14-56.

Tyszka P., 1995, O metodzie badań nad średniowiecznymi granicami lokalnymi, „Kwartalnik Historii Kultury Materialnej”, 43 (4), s. 423-431.

Tyszkiewicz J., 2014, Geografia historyczna. Zarys problematyki, Warszawa.

Woźniak K.P., 2013, Niemieckie osadnictwo wiejskie między Prosna a Pilica i Wisła od lat 70. XVIII wieku do 1866 r. Proces i jego interpretacje, Łódź.

Zimmermann K., 1915, Fryderyk Wielki i jego kolonizacja na ziemiach polskich, t. 1-2, Poznań. 


\title{
Remarks on the process of shaping the village boundaries in Poland until the end of the eighteenth century in the morphogenetic context
}

\begin{abstract}
Summary
The article discusses the process of shaping the boundaries of the rural settlements in Poland until the end of the eighteenth century. Analysis of the procedures of delimitation and demarcation of limits in the cultural landscape of the village was carried out on the basis of the collected historical sources in the form of documents, descriptive materials and judicial maps in the confrontation with the results of geographical and historical research. In this work the problem of forming the boundaries was also connected with the issue of the morphogenesis of villages. The process of so called ujazd was the most important form of shaping the spatial extent of the villages in the Middle Ages. During the feudalization of social relations one can indicate the process of linearization of zonal boundaries. The course of demarcation gradually changed in the context of codification of border law. On the basis of comparative analysis of internal limits of the medieval villages one can identify the regular and irregular forms of layout. External limits and geometric form of village depended mainly on the temporal sequence of settlements formation. In the Modern Period the institutionalization of shaping the boundaries occurred in association with the development of the land jurisdiction. In this context, complex procedures of demarcation were commonly used, taking into account the ways of limitation and border marks used in the field. New measurement techniques and maps of border disputes were also an important innovation of demarcation. Rural settlements from that period were varied from the point of view of internal and external limits. Villages formed in the process of so called pomiara wtóczna, Frederician colonization and some Olęder villages showed a high degree of regularity of internal division, and their external limits were clearly dominated by linear segments. A significant part of the manorial villages, pre-industrial settlements and a part of the Olęder villages were much less regular, both in terms of internal divisions and external limits.
\end{abstract}

Key words: boundary, village, settlement, Poland.

Tomasz Figlus, dr

Katedra Geografii Politycznej i Studiów Regionalnych, Wydział Nauk Geograficznych, Uniwersytet Łódzki, 90-142 Łódź, ul. Kopcińskiego 31 